\title{
Designing Web-Based Learning Materials
}

\author{
Blanka Frydrychová Klímová, Petra Poulová \\ Faculty of Informatics and Management \\ University of Hradec Králové \\ Hradec Králové, Czech republic
}

\begin{abstract}
Online courses are nowadays well established forms of learning and teaching all over the world. They are used as supporting courses of traditional classes, as complementary courses of blended courses or pure distance courses. In all cases they must be designed well to attract and motivate students. Therefore, this paper focuses on the analysis of web-based study materials and their impact on learning.
\end{abstract}

Keywords: - eLearning, online courses, learning, teaching, study materials, survey

\section{INTRODUCTION}

The Faculty of Informatics and Management of the University of Hradec Králové (FIM UHK) has been intensely involved in the application of web-based education since 1997. The e-courses are created in a Virtual Learning Environment called OLIVA based on Learning Management System (LMS) Blackboard Learn.

At present, more than 220 e-courses are offered. Some of them can be taught completely online. However, most of them are blended as there are usually a few tutorials. At tutorials (face-to-face teaching) students usually discuss the problems they come across when doing different types of tasks or writing assignments. Moreover, sometimes there are regular classes and e-courses are used as reference courses (i.e. students can once again read the information obtained in class and do some additional exercises to practice their knowledge) [1].

In the web-based course students especially exploit the study materials, which undoubtedly play a crucial role in the acquisition of their knowledge and skills. Moreover, not much hands-on research has been done in this field yet. Therefore, this paper focuses on the development of web-based materials and their impact on learning, cf. [2]

\section{DEVELOPMENT OF WEB-BASED LEARNING MATERIALS}

Authors provide the following simple framework for the creation of any topic-based study materials [3]:

1. Maximally a two page document [4], [5] consisting of the following items:

- topic (a concise sentence or a phrase of the lesson content);
- learning goal/ outcome (a short statement motivating the participants to study the particular lesson);

- $\quad$ prerequisites (previous knowledge required to master the lesson);

- skills (a description of the knowledge/ skills to be gained in the particular lesson);

- explanation of the basic concept and ideas (in the form of text and questions);

- conclusion with self-tests, tasks, quizzes (with keys), or an assignment;

- bibliographical sources and or links to them

2. For creating the main content of the lecture, bullet points should be used. Pictures, tables or graphs where desirable should be included,

3. Short sentences, involving 20 words at maximum should be formed [6], [7].

LMS WebCT/Blackboard provides many enhancements to help teachers to publish their study materials. Teacher can become a course creator that can easily publish his/ her elaborated materials. The process of publishing materials in the web-based system consists of several steps:

- materials preparation;

- materials conversion into HTML format;

- materials uploading into web-based system;

- linking page from the content module (outline of the course);

- $\quad$ linking tests, quizzes and assignments if necessary.

Furthermore, the LMS WebCT/Blackboard helps to track students' work and time spent in the online course. In addition, it enables a teacher/ tutor to encourage students in their learning with the help of communication tools, such as e-mail or discussion. [9] Moreover, it can motivate students in their learning by providing them with feedback on their assignments. [10] 


\section{RESEARCH AND ITS FINDINGS}

In order to find the latest attitude of FIM UHK students to the web-based study materials, authors made a survey. The survey concentrated on the eLearning form of study with respect to the study materials. The results were processed with the help of standard statistical methods.

Overall, 484 students participated in the survey. 64\% formed men and $36 \%$ women (Fig. 1), which in fact reflects the nature of the faculty since most respondents were from the field of informatics: applied informatics (AI), information management (IM) and information and knowledge management (IZM) - 360, other respondents studied financial management (FM - 27), sport management (SM - 17) and management of tourism (MCR - 56) - see Fig. 2.

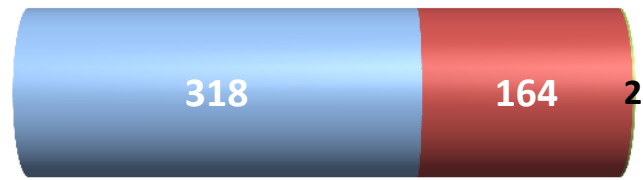

\section{man female without answer}

Fig. 1. Respondent's sex

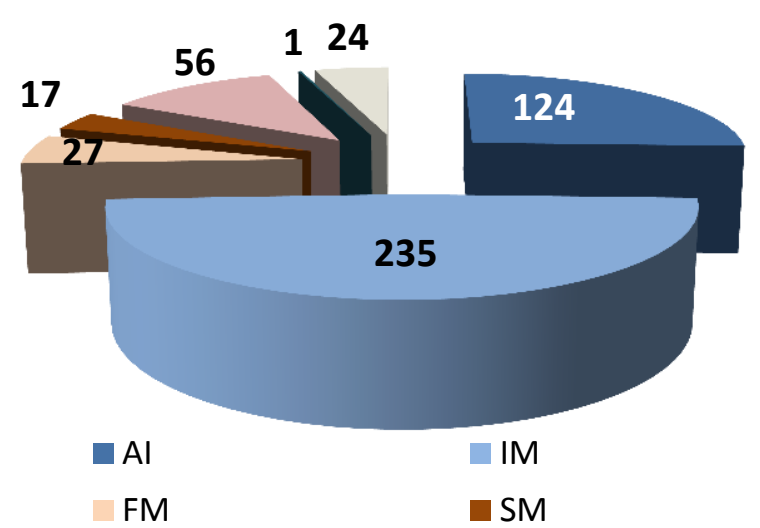

Fig. 2. Respondent's field of study

An average age of the respondents was 22 years.

Students have much experience in working with e-subjects because 191 of them admitted studying 2-5 e-courses and 101 of them even worked in more than 10 e-courses. See Fig. 3.

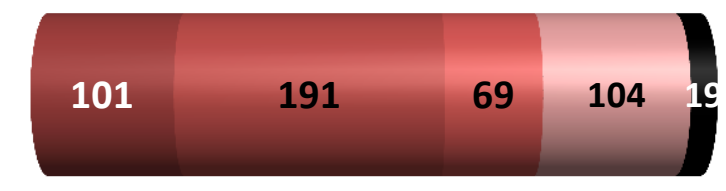

$\square 1 \square 2$ - $5 \square 6$ - $10 \square$ more than $10 \square$ without answer

Fig. 3. Experience in working with e-subjects

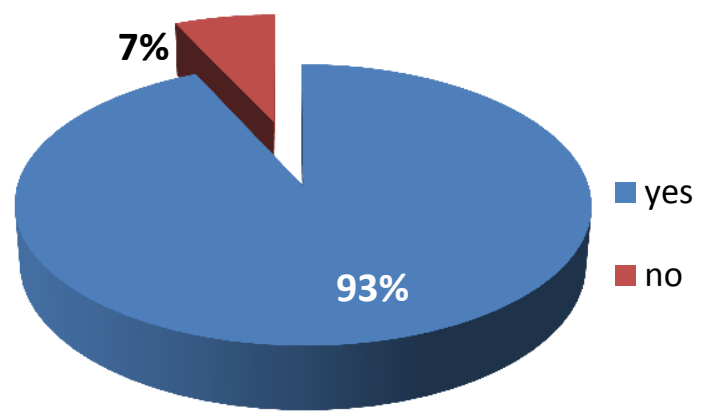

Fig. 4. Form of study

The survey revealed that most respondents (58\%) preferred blended classes to the traditional, face-to-face classes $(33 \%)$ and only $9 \%$ of respondents would rather have the online classes only (Fig. 5).

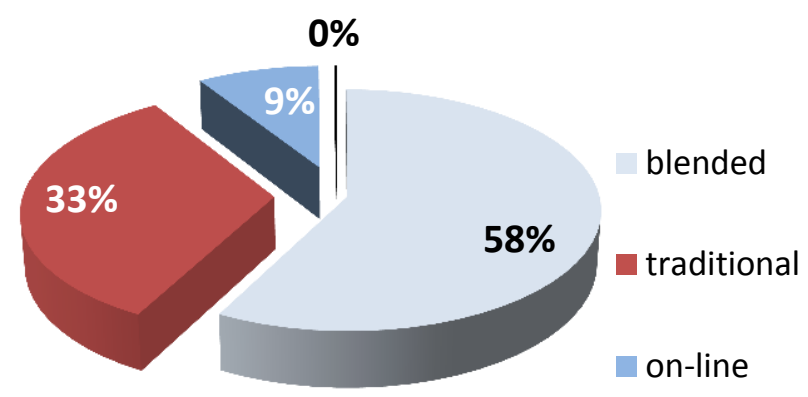

Fig. 5. Preferred classes

The survey confirmed that the most exploited eLearning tools are study materials (459 respondents), followed by assignments, quizzes, and self-tests (180 respondents). (Fig. 6) 


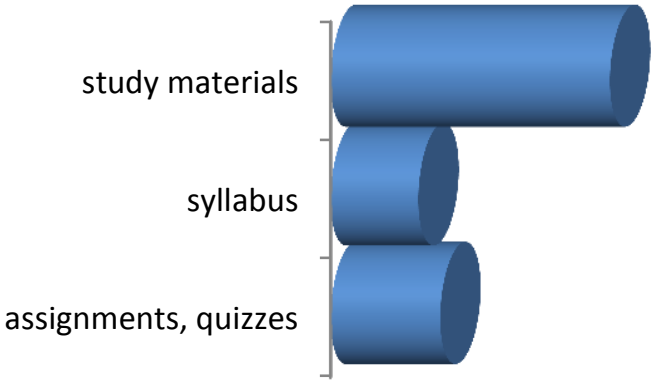

Fig. 6. Exploitation of tools

An overwhelming majority of students (96\%) found the electronic texts easy to read in comparison with a dissatisfied minority. (Fig. 7)

The main reasons of respondent's dissatisfaction:

- complexity of study materials;

- unclear subsections in which it is difficult to find something;

- more structures information in bullets is needed;

- often a chaotic storehouse of documents;

- the texts often contain abbreviations which are not explained;

- the texts are sometimes more difficult to understand..

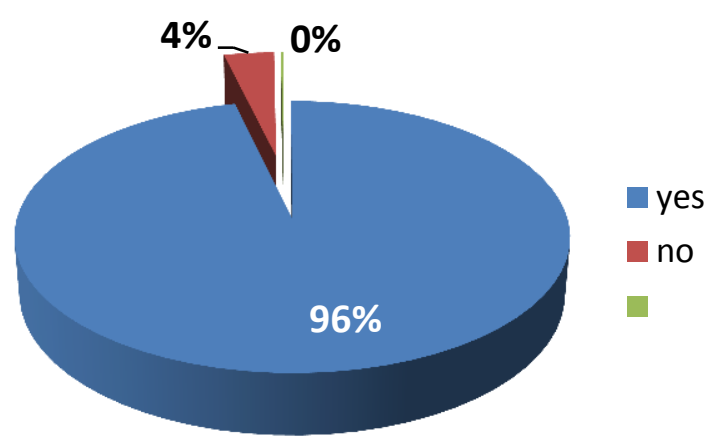

Fig. 7 Preferred form

Furthermore, $93 \%$ of respondents were satisfied with the content structure of their electronic materials. (Fig. 8)

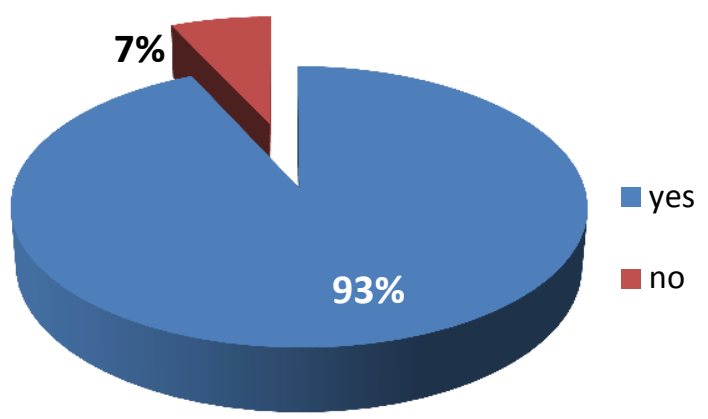

Fig. 8 Satisfaction with the content structure

287 students also answered question 5: What do you like in your written electronic materials most? Majority of replies (almost 50\%) concerned their accessibility. Students really appreciate accessing the study materials at any time and at any place, most preferably from the cosiness of their homes. Other positive factors of the electronic materials are as follows:

- a possibility of copying, downloading and printing;

- an easy access to study materials;

- low/no costs of learning materials;

- everything that is needed for study in one place;

- simplicity.

\section{CONCLUSION}

From the described results of the survey, it is clear that students welcome an opportunity to work with web-based courses. The reason is that they can complete their knowledge and thus finish their learning process, which they did not manage to do during the face-to-face classes, cf. [8]. Therefore, tutors should pay a careful attention to their creation.

As both theory and practice (survey) revealed:

- Study materials should have a clear, logical and simple structure

- The materials should be up-to-date.

- They should be easily navigated.

- They should be interactive with multimedia components.

If such a material is developed, then both teaching and learning is a challenge.

\section{REFERENCES:}

[1] Frydrychová Klímová, B. \& Poulová, P. Reflection on the development of eLearning in the Czech Republic. Proceedings of the 16th WSEAS International Conference on Recent Researches in Communications and Computers. WSEAS: Corfu, 2012. pp. 433-437. 
[2] Sedleniece, M. \& Cakula, S. Framework for personalized e-learning model. Proceedings of the 16th WSEAS International Conference on Recent Researches in Communications and Computers. WSEAS: Corfu, 2012. pp. 457-462.

[3] Frydrychová Klímová, B. Teaching formal written English. Gaudeamus: Hradec Králové. 2012.

[4] Malír, F. 33 poznámek k pedagogice, didaktice cizích jazyků a didaktice angličtiny. Cizi jazyky, 51(2), pp. 38-41. 2007

[5] Murphy, R. English grammar in use. Cambridge: CUP. 1985.

[6] Bednaříková, I.. Didaktické aspekty učiva a e-learning. In J. Sedláček (Ed.), Sborník príspěvků ze semináře a soutěže e-learning 2003. Hradec Králové: Gaudeamus, pp. 164-171. 2003

[7] Dunleavy, P. Authoring a PhD. Palgrave: Macmillan. 2003

[8] Stoykova, V. Formal representations of Bulgarian possessive and reflexive-possessive pronouns. Recent Researches in Information Science and Applications. WSEAS Press, 2013, pp. 144-149.

[9] Simonova, I.. Communication in Online Courses under the Virtual Observation: Case Study. Proceedings of the 11th WSEAS

International Conference on Education and Educational Technology (EDU '12). WSEAS Press, 2012, pp. 82- 88

[10] Subrt, J., Valisova, A. New Media and the Educational Process: The Problem of Time and Memory. Proceedings of the 11th WSEAS International Conference on Education and Educational Technology (EDU '12). WSEAS Press, 2012, pp. $100-104$.

\section{Creative Commons Attribution License 4.0 (Attribution 4.0 International, CC BY 4.0)}

This article is published under the terms of the Creative Commons Attribution License 4.0

https://creativecommons.org/licenses/by/4.0/deed.en US 